\title{
Korean Crisis and a War of Words
}

\author{
Joanna Beczkowska
}

University of Lodz

Faculty of International and Political Studies

Department of Asian Studies

e-mail: joanna.beczkowska@uni.lodz.pl

\section{Abstract}

In 2017, Korean crisis escalated as Donald Trump began "war of words" with DPRK's chairman Kim Jong-un. Each threat both leaders made might eventually be understood by the other party as a declaration of war. Donald Trump wanted to "clean up the mess" left by previous US administrations and solve the problem of North Korean nuclear program. However, his actions were inconsistent: he threatened in a very North Korean way "total destruction" only to emphasize later that it was not a "preferred option." This article explores how "war of words" was a significant cause of the escalation of the Korean crisis.

Keywords: North Korea, Korean Peninsula, Donald Trump, Kim Jong-un, nuclear crisis, USA-North Korea relations. 


\section{Introduction}

The first year of Donald Trump's presidency coincided with the significant progress in the development of North Korea's nuclear program. In the New Year's address, the North Korean leader Kim Jong-un declared that the Democratic People's Republic of Korea (DPRK) has "entered the final stage of preparation for the test launch of an intercontinental ballistic missile" (2017 New Year's Address). Donald Trump, who in the same month was to be sworn in as president of the United States, via Twitter assured that “it won’t happen!” (@realDonaldTrump). A few months later, the North Korean media announced that a successful test of ballistic missile which can "reach anywhere in the world" was carried out. This event, however, was not the beginning of recent Korean crisis but the result of the growing tension on the Korean Peninsula. One of the major reasons for the increase in tension in 2017 was none other than Donald Trump and his war of words against North Korean leader.

This article aims to show how Trump's policy affected the escalation of tension on the Korean Peninsula in 2017. The problem of North Korea's nuclear and missile armaments may be one of the most important challenges of Trump's foreign policy. The American president has repeatedly promised to "clean up the mess" left by his predecessors. However, in 2017 Donald Trump was far from solving the problem of DPRK's denuclearization at the negotiating table: his threatening policy turned into a war of words which could very easily become armed conflict. The tension between Washington and Pyongyang also limited the possibilities of South Korean President Moon Jae-in who together with the liberal Democratic Party replaced the conservative Park Geun-hye government. The new South Korean administration faced the difficult task of balancing between the expectations of the international community (sanctions of the United Nations Security Council towards North Korea), the alliance with Washington, and the desire to improve inter-Korean relations.

The leading figures of the Korean crisis - Donald Trump and Kim Jong-un - aroused among the international community concerns due to their unpredictability. Although the American president blamed only the North Korean side for contributing to the escalation of the conflict, this article proves that growing tension on the Korean Peninsula was in fact the combination of Trump's incoherent strategy and aggressive rhetoric with the rapid development of nuclear weapon by DPRK.

\section{United States-North Korea relations}

Relations between the United States and North Korea are characterized by uncertain advances towards denuclearization that ended with deadlock and crisis. Pyongyang for years has been blackmailing the international community with the threat of using 
nuclear weapons, from time to time signalling readiness to sit at the negotiating table. In this way, the North Korean regime has often avoided strong reprisals from the American side. The strategy of DPRK led by Kim Il-sung and Kim Jong-il consisted of making promises to the United States and international community in the moments of danger - such as collapse of the Soviet Union: the most important ally of North Korea - to abandon nuclear weapon only to blur them later during negotiation process with Washington (Courmont, 59). On the other hand, the United States undertook various political actions in response to threats from North Korean proliferation. These include military cooperation with allies in the region (Japan, South Korea), extensive sanctions and non-proliferation mechanisms such as export controls. In addition, Washington has been involved in diplomatic initiatives that offered North Korea humanitarian aid and some concessions in exchange for abandoning the nuclear program. The North Korean strategy can be well illustrated by regime's policy in the 1990s. In 1985, Pyongyang signed the Treaty on the Non-Proliferation of Nuclear Weapons, however the process of negotiations with the international community did not truly begin until the Soviet Union's collapse. Kim Il-sung and then Kim Jong-il used apparent openness to achieve their own goals. After each progress in the negotiations, there was always a step back. And so North Korea did not comply with the guidelines of the International Atomic Energy Commission, demanding that the United States first withdrew its tactical nuclear weapons from South Korea. In 1991, President George Bush supported the gradual withdrawal of American forces from Asia, including tactical nuclear weapons. Following Bush's example, South Korean President Roh Tae-woo announced the Declaration on the Denuclearization of the Korean Peninsula, which was then signed by both Koreas. Only two years later North Korea rejected one of the important points of inter-Korean agreement: declaration on mutual control of both countries. Pyongyang again resorted to blackmail and threatened to withdraw from the non-proliferation treaty, demanding a security guarantee from the United States. After obtaining it, Kim Il-sung agreed to the inspection but only under his conditions. In 1994, his successor, Kim Jong-il, seemed to finally end negotiations with Washington by agreeing to close the nuclear program. In return he demanded large compensation from United States. However, instead of solving nuclear crisis, this was the beginning of using by DPRK strategy of making the promises of ending nuclear armaments in exchange for financial gain.

The North Korean leaders proved to be great manipulators. The main goal of the North Korean regime was and is to survive. Without the support of traditional allies North Korea decided to bet on nuclear weapons to effectively deter enemies. The example of US-North Korean relations under the Bush administration shows how efficiently the regime has used the strategy of threats intertwined with apparent openness to negotiations. Moreover, North Korea finally managed to blame in the eyes of international community the US for the impasse in the negotiations. Pyongyang has repeatedly invoked (and still is) that insufficient security guarantees 
from Washington are the sole reason which does not allow the final closure of the nuclear program issue.

Interestingly, the escalations of tensions in the Korean Peninsula, which usually turned into a dangerous crisis, were often actually caused by the United States. The coming to power of the Republicans and the terrorist attack of September 11, 2001 greatly affected the deterioration of the Washington-Pyongyang relations. In the US government, the position of hard-line supporters who advocated a confrontational attitude towards North Korea was strengthened (Courmont, 71). President George W. Bush continued to attack Kim Jong-il, calling him names like "spoiled child" or "pygmy" (an allusion to Kim's short height). Moreover, American president also condemned the peaceful efforts of Kim Dae-jung, whose "sunshine policy" improved relations on the Korean peninsula. The aggressive rhetoric of the American president probably influenced the increase in North Korean radicalism. When Washington came up with the idea of a military solution to the problem of North Korean nuclear weapon, Pyongyang had no other choice but to strongly manifest its power: in 2003 DPRK announced withdrawal from the Treaty on the Non-Proliferation of Nuclear Weapons, and a few months later officially admitted to possessing a nuclear weapon. The six-party talks ended with a stalemate, for which the North Korean side could again blame the United States. George W. Bush included DPRK along Iran and Iraq in "axis of evil." This term was used by Bush administration in place of "rogue state" to describe governments that developed weapons of mass destruction and sponsored terrorism. Concept turned out to be very controversial: the United States used it as justification of war on terrorism while critics saw it rather as justification of imperialism and propaganda tool. Armed intervention in Iraq proved the failure of "axis of evil" concept that no longer could be efficiently used against North Korea.

Return of Democrats to power and the election of Barack Obama as a new president brought back policy of "engagement" instead of confrontation. Obama, unlike previous American leaders, realized that Kim Jong-il is not a madman but a rational strategist. The solution to the problem of North Korean nuclear weapon should lie in understanding the interests of Pyongyang, not intimidation of regime. Obama also called for the extension of the dialogue to other issues instead of focusing only on denuclearization. However, Obama administration policy was too passive to solve the problem and, after attack on the island of Yeonpyeong, Pyongyang only intensified various provocations.

\section{The end of the era of strategic patience}

Donald Trump's rise to power coincided with the final stage of consolidation of power by the son of Kim Jong-il. Kim Jong-un like Trump appears to be an unpredictable politician. Despite the tightening of sanctions and the threat of armed 
intervention by the United States, North Korea carried out further rocket and nuclear tests. However, the intense development of the nuclear program and the purges among the party elites were, first and foremost, important for Kim's internal policy: he had to strengthen his position as the undisputed leader. In a sense, Trump faced a similar task: he had to prove his greatness as a president. The solution to this could be resolving the problem that previous American leaders dealt with without much luck.

After rising to power, Donald Trump announced the end of the era of "strategic patience." He declared that, unlike his predecessors, he would solve the North Korean problem once and for all. However, instead of offering a coherent strategy, Trump got into a word skirmish with the North Korean leader and his associates from time to time had to assure the international community that the conflict should be resolved first by peaceful means. The escalation of tension between Washington and Pyongyang took place in April 2017. North Korea launched a mid-range ballistic missile towards the Sea of Japan. Two days later Trump manifested his strength by launching a missile attack in Syria. The USS Carl Vinson aircraft carrier was then directed towards the Korean Peninsula. This was allegedly the result of a communication error. The commemoration of the $85^{\text {th }}$ anniversary of the founding of the Korean People's Army which was accompanied by demonstration of military manoeuvres also contributed to the increase in tension. Moreover, the US missile system THAAD was installed in South Korea. In July, North Korea conducted an intercontinental ballistic missile test and then threatened to attack the American military base on the island of Guam. At that time, threats were often exchanged between the leaders of both countries.

The situation seemed dangerous. When George W. Bush insulted Kim Jong-il, the North Korean leader did not turn to an exchange of insults. Kim Jong-un, on the other hand, did not remain indifferent to Donald Trump's threats. It was feared that being provoked, young leader of North Korea would reach for nuclear weapons. According to Korean Central News Agency, before launching an intercontinental missile Kim said that "American bastards" would not be happy with such a gift on $4^{\text {th }}$ of July (qtd. in A gift for American bastards). In August, the UN Security Council imposed new sanctions on Pyongyang. UN sanctions aimed at the economy of this isolated country are major obstacle for regime. Kim had to respond to it and the aim of his attack was again the United States which was to "pay for its crimes". The escalation of the war of words took place during the aggressive speech of Donald Trump at the UN General Assembly meeting. Then Donald Trump promised to "completely destroy North Korea" (Remarks by President Trump to the $72^{\text {nd }}$ Session of the United Nations General Assembly). Although this statement could have been read as a declaration of war, the North Korean regime decided to apply its strategy of threatening and withdrawing from them when situation becomes too dangerous. Kim Jong-un announced that he would not make 
the promised attack on Guam but instead wait to see the "foolish and stupid conduct of the Yankees" (qtd. in North Korea backs off Guam threat). All responsibility for a possible further escalation of the Korean crisis was dropped on the American side. The North Korean leader called by Trump a "madman" was to advise the United States to "think rationally and make a precise decision to avoid humiliation" (qtd. in North Korea backs off Guam threat).

In this war of words, the rhetoric of Donald Trump is surprising. Using social media, the American president posted many statements that were far from diplomatic correctness. In response to the threat of attack on Guam, a statement appeared in the media that the next provocations "will be met with fire and fury like the world has never seen." These words, though spoken in the style of the North Korean regime, were said by Donald Trump (qtd. in Trump says North Korea will be met with 'fire and fury'). Those words may sound familiar, as DPRK many times threatened to turn South Korea into a "sea of fire." The next tweets of the American president about the increase of the nuclear arsenal and the statement that "there will never be a time that we are not the most powerful nation in the world!!" also sound like heard in North Korean propaganda speeches (@realDonaldTrump). The statements of both leaders adopted a very similar tone. However, what is characteristic of the North Korean regime is seen as the failure of American diplomacy. Donald Trump lowered himself to the "level" of his opponent, thus losing the skirmish with him at the beginning. When Donald Trump called Kim "a rocket man on a suicide mission" and threatened to completely destroy North Korea, if he was forced to do so (Remarks by President Trump to the $72^{\text {nd }}$ Session of the United Nations General Assembly), Pyongyang responded by saying "a frightened dog barks louder" (qtd. in North Korea: Kim Jong-un's statement about 'deranged dotard' Donald Trump). Kim Jong-un realized that the tougher Trump's rhetoric, the smaller the threat. Donald Trump's words could also be used against the United States, indicating that it is Trump, not Kim, who is a greater threat to peace in the Korean Peninsula.

\section{Are all options for North Korea actually on the table?}

The most important issue related to the war on words is the question of whether it can turn into a military battle. After Donald Trump's speech at the UN General Assembly, his spokesperson Sarah Huckabee Sanders assured that the United States did not declare war on North Korea (qtd. in North Korea $v$ Donald Trump war of words: a most dangerous game). But how could the regime in Pyongyang understand threats such as "total destruction"? The American president gave Kim an argument for the further development of the nuclear program to defend the country. North Korean leadership also realizes that a preventive USA attack is unlikely, and 
Trump's threats are nothing more than words. DPRK has been playing this game with Washington for years and perfectly knows when it can afford to threat, and when it is time to reduce provocations. More than two decades of WashingtonPyongyang relations after the end of the Cold War shows that the United States will not start a war if North Korea does not attack directly. In 2010, a former US military pilot confessed that Richard Nixon was considering dropping the atomic bomb at Pyongyang, but he never decided to take this step. When the North Korean torpedo sank the South Korean Cheonan corvette, Barack Obama directed military ships and planes toward the Korean Peninsula, but he did not strike. Both politicians were praised for their restraint towards North Korea. All states involved in this conflict: the United States, North and South Korea, Russia, China and Japan want to avoid the outbreak of a new war on the Korean Peninsula. For years, the main goal of the North Korean regime is - as mentioned - survival, and the nuclear arsenal is to be the guarantor. The North Korean weapon thus acts as a deterrent and is not offensive. The United States, on the other hand, realizes that an attack on the regime would pose a threat to South Korea and Japan, if not to the Americans themselves, and would mean huge losses in people. China would also like to avoid a war: not only because the collapse of the Kim Jong-un regime would mean a huge influx of refugees, but also because of the possibility of the US and South Korean troops stationing close to China's borders.

Rhetoric of both Trump and Kim is full of hidden "ifs." It is true that all the options are on the table but that does not mean they will ever be used. Trump threatens with total destruction again and again, immediately adding that this is not the preferred option. North Korea continues its tactics of intimidating with nuclear weapons in response to American threats, at the same time presenting its arsenal as a legitimate means of defence, not an attack. In the entire Korean crisis, Donald Trump remained the biggest unknown. One day on Twitter he could say that his patience was over, and Pyongyang's threats were enough to decide to wipe this country off the face of the earth, just to praise Kim Jong-un the other day. Even the closest advisors of the American president were not sure whether this was part of strategy to intimidate Kim or just the emotional explosion of Trump (North Korea $v$ Donald Trump war of words: a most dangerous game).

Kim Jong-un, on the other hand, continued the policy of provocation while not exceeding the limit of provoking armed conflict with Washington and Seoul. DPRK has an undeniable advantage in the form of nuclear weapons. A weapon of this type has a special status: as no other is raising such fear as the prospect of destroying mankind. The international community, which is often lead by the United States must face the threat of its use even if it is only hypothetical. Therefore, the United States decided to invade Iraq on the pretext of eliminating the weapons of mass destruction which allegedly was in the possession of the regime of Saddam Hussein and never took steps towards North Korea which is openly manifesting its nuclear 
potential. Washington was sure that Iraq would not respond with a nuclear attack. Even if the Kims are bluffing and their rockets are not capable of transferring the appropriate nuclear warheads, this possibility exists: if not now, then in the future. That is the reason why Donald Trump despite threatening to put all options on the table is unable to use them without jeopardizing the lives of many US, South Korean or Japanese citizens.

\section{Trump Scarier Than Kim}

Due to its location and relations, South Korea must participate in the conflict between Washington and Pyongyang. Seoul which is located not far from the border with North Korea would easily become a target in the event of a war. However, living in constant feeling of danger from North Korean side over time turned into a habit. Many South Koreans admitted that they actually are more afraid of the American president than the leaders of the North Korean regime. According to some Koreans, Donald Trump is responsible for the escalation of tension on the Korean Peninsula. The unpredictability of the American president and his hasty statements may lead North Korea to attack. According to the South Koreans, Kim Jong-un "says something crazy that he is going to do but he has never done anything," while Donald Trump "by his action" can provoke the young leader (qtd. in "Trump might start a war'). South Koreans are afraid that the American president trying to prove something to the world and confirm his authority only increases tension on the Korean Peninsula instead of solving the problem of North Korean nuclear program. Relations with Washington under the leadership of Donald Trump seem problematic not only for the enemy North Korea but also for the American allies like South Korea. In 2017, the conservative administration of Park Geun-hye was replaced by the social-liberal Democratic Party and Moon Jae-in who is influenced by his mentor Roh Moo-hyun. Roh continued Kim Dae-jung's "sunshine policy" and was known for his anti-American attitude (Manyin, 9-10). However, Moon Jae-in in 2017, when North Korea was rapidly developing its nuclear program, could not easily follow footsteps of "sunshine policy" and thus proposed "two-track approach." This strategy means striving to resume dialogue with Pyongyang and establish humanitarian cooperation while respecting the sanctions of the UN Security Council. In addition to the Security Council sanctions, cooperation activities with Pyongyang have been limited for Seoul by the alliance with the United States. The foreign policy of Donald Trump "America First" was a challenge for Moon Jae-in. Renegotiation of the free trade agreement, the demand to cover most of the costs of implementing and servicing the THAAD missile system, and above all the escalation of the Korean crisis by threats of using military power contributed to the growth of antiAmerican sentiments in South Korea. At the same time, the administration of Moon 
Jae-in was aware of the importance of an alliance with the United States which is a guarantee of security. That is why Seoul supports American sanctions and participates in joint military manoeuvres even though such actions always raise objections from the North Korean side. Even the achievement of the inter-Korean negotiations on the Olympic Games was partly attributed to Trump by the South Korean government. It was hoped that in this way Trump would not "interfere," which would contribute to the de-escalation of the crisis.

\section{Conclusion - Defeat of Trump}

Kim Jong-un was the winner of war of words in 2017. Although North Korea was significantly weakened by the international sanctions of the UN Security Council, it managed to accelerate the development of the nuclear and missile programs. At the beginning of the year, Donald Trump assured that he would not allow Pyongyang to create a nuclear weapon that can reach the United States. If you believe the assurances of the North Korean side, however, Trump did not manage to stop the technological progress of Pyongyang. Tests of a ballistic missile with an intercontinental range should be evidence of that. Moreover, the American president provided the regime with the necessary arguments for propaganda inside and outside the country. The biggest threat to North Korea is actually self-destruction. However, Trump's "fire and rage" rhetoric has only strengthened Kim Jong-un's position within the state. The threat from the United States justified the spending on nuclear program.

Barack Obama's policy of "strategic patience" did not work but Donald Trump has not offered a more effective strategy. Taking over the rhetoric from Pyongyang, the American president wanted to "tame" North Korea with fire. However, these threats were empty, and Kim Jong-un could further develop its weapons program. At the moment of the escalation of the conflict, it was feared that Trump's threats would be understood as a declaration of war. In such an atmosphere, joint military manoeuvres of the United States and allies near the Korean Peninsula could be easily read by Pyongyang as an imminent threat.

Trump's administration policy towards North Korea turned out to be inconsistent. When Donald Trump threatened "total destruction," Secretary of State Rex Tillerson and Secretary of Defence James Mattis assured that Washington's goal was not war but diplomatic solution. This incoherence could have been used by Kim to "examine" how much he could afford in provoking the United States. This combination of Washington's vague policy, the escalation of tension and the possibility of Kim "crossing the border" posed a threat of armed conflict. Although in early 2018 the tension on the Korean Peninsula was reduced by the participation of North Korea in the Winter Olympics, the threat of armed conflict still exists. 
Was the beginning of 2018 the end of Korean crisis? In his New Year's address Kim Jong-un announced his will to improve relations with South Korea. At the same time, he did not forget to add that there is a "nuclear button" on his desk that can be pressed at any moment. In January 2018, eyes of the international community focused on photos of ministers of both Koreas who sat down in demilitarized zone to talk about the participation of North Korea in the Winter Olympic Games organized by South Korea. However, this does not mean the end of the crisis: it is a well-known scheme of North Korean activities - after the escalation of tension there is an apparent openness to dialogue. The efforts of the South Korean President Moon Jae-in who strives to maintain this dialogue mean little because two factors that have had an impact on the crisis that began in 2017 - North Korean regime sense of being in danger and Donald Trump - still play a major role on Korean Peninsula. At any moment of deadlock in negotiations, a new war (of words) between Trump and Kim can break out.

\section{Works Cited}

@realDonaldTrump (Donald Trump).... Hopefully we will never have to use this power, but there will never be a time that we are not the most powerful nation in the world! Twitter (9 Aug. 2017, 05:03), twitter.com/realDonaldTrump/ status/895254168570605568

@ realDonaldTrump (Donald Trump). North Korea just stated that it is in the final stages of developing a nuclear weapon capable of reaching parts of the US It won't happen!" Twitter (2 Jan. 2017, 3:05), twitter.com/realDonaldTrump/ status/816057920223846400

Bedminister, N.J. Trump Says North Korea Will Be Met with 'Fire and Fury' If It... “Reuters”, Thomson Reuters (8 Aug. 2017). Web. 14 Sept. 2018, www.reuters.com/ article/us-northkorea-missiles-usa-trump/trump-says-north-korea-will-be-metwith-fire-and-fury-if-it-threatens-u-s-idUSKBN1AO28O.

Courmont, B. Korea Pótnocna. Paradoksy Polityki Kimów [North Korea. Paradoxes of the Kims Policy]. Translated by Elżbieta Brzozowska. Warsaw: Wydawnictwo Akademickie Dialog, 2011.

Kim, J. Kim Jong Un's 2017 New Year's Address. The National Committee on North Korea (1 Jan. 2017). Web. 14 Sept. 2018, https://www.ncnk.org/resources/ publications/kju_2017_new_years_address.pdf/file_view.

Lee, R. North Korea Backs off Guam Threat. “The Korea Times", Hankook Ilbo (15 Aug. 2017). Web. 14 Sept. 2018, www.koreatimes.co.kr/www/nation/2017/08/ 103_234766.html. 
Manyin, M.E. South Korean Politics and Rising "Anti-Americanism": Implications for US Policy Toward North Korea. Washington, DC: Congressional Research Service, 2003.

McCurry, J. "A Gift for the American Bastards": North Korea's Kim Fires Back at Donald Trump. "The Guardian", Guardian News and Media (5 July 2017). Web. 14 Sept. 2018, www.theguardian.com/world/2017/jul/05/a-gift-for-the-american -bastards-north-koreas-kim-fires-back-at-trump.

McGeough, P. North Korea $v$ Donald Trump War of Words: A Most Dangerous Game. "The Sydney Morning Herald" (26 Sept. 2017). Web. 14 Sept. 2018, http:// www.smh.com.au/world/north-korea-v-donald-trump-war-of-words-a-mostdangerous-game-20170925-gyopzk.htm.

North Korea: Kim Jong-un's Statement about 'deranged Dotard' Donald Trump. "The Independent". Independent Digital News and Media (22 Sept. 2017). Web. 14 Sept. 2018, https://www.independent.co.uk/news/world/asia/northkorea-kim-jong-un-donald-trump-statement-in-full-nuclear-weapons-dotardkcna-a7960476.html.

Robinson, B. "Trump Might Start a War" South Koreans Fear US President MORE than Kim Jong-un. Express.co.uk. Northern and Shell Media (10 Aug. 2017). Web. 14 Sept. 2018, https://www.express.co.uk/news/world/839602/South-Koreansscared-of-Donald-Trump-war-with-North-Korea-nuclear-missiles-fire-and-fury. Trump, D. Remarks by President Trump to the 72nd Session of the United Nations General Assembly. The White House. The United States Government (19 Sept. 2017). Web. 14 Sept. 2018, https://www.whitehouse.gov/briefings-statements/ remarks-president-trump-72nd-session-united-nations-general-assembly/.

Joanna Beczkowska - a junior research fellow at Center for Asian Affairs and $\mathrm{PhD}$ student at the Department of Asia Studies as part of the Interdisciplinary Humanist Doctoral Studies at the University of Lodz. She is a graduate of the Faculty of Philology (cultural studies, specialty film studies) and the Faculty of International and Political Studies at the University of Lodz (international relations). Her research interests include issues related to politics, society and culture of South Korea and inter-Korean relations. 